\title{
Looking Toward a Brighter Future for Lekking Grouse
}

\section{By Chad Boyd, Steven Petersen, Wendell Gilgert, Randy Rodgers, Sam Fuhlendorf, Randy Larsen, Don Wolfe, K. C. Jensen, Phil Gonzales, Melvin Nenneman, Rick Danvir, David Dahlgren, and Terry Messmer}

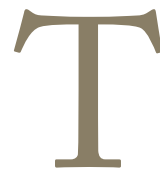

he current range of lekking grouse, including greater sage-grouse (Centrocercus urophasianus), Gunnison sage-grouse (C. minimus), sharp-tailed grouse (Tympanuchus phasianellus), greater prairiechickens (T. cupido), and lesser prairie-chickens (T. pallidicinctus), covers much of the rangeland in the western and central United States, as well as portions of southwestern and south central Canada. ${ }^{1-4}$ All of these species have experienced generalized population declines within their range. Additionally, all lekking species (or subspecies of these species) in North America have been or are being petitioned for protection under the US Endangered Species Act. The legal status of lekking grouse has the potential to alter the management of rangeland resources, and management of those resources, in turn, influences the population status of lekking grouse. Although many publications have described in detail the decline and possible causes of decline in lekking grouse populations and associated habitats, only limited information is available to suggest habitat management practices that benefit these species. This lack of information not only complicates matters for managers trying to increase habitat availability or quality, but encourages a reactive approach to management of lekking grouse that often emphasizes the depth of the problem rather than the nature of the solution.

Given the lack of published information on "what works," a symposium was held at the 2010 Society for Range Management meeting to highlight a selection of positive management and research advances in the conservation of lekking grouse species. The presentations from this symposium serve as the backbone for this article. Our effort is not comprehensive to all issues facing lekking grouse, but instead highlights successful or promising habitat management practices and strategies, as well as notable advances in our understanding of lekking grouse habitat.

Because much of the information presented in the symposium originated from 1) after-the-fact case studies and 2) large-scale issues such as habitat dynamics and regional efforts to mobilize a diversity of stakeholders, across-the-board extrapolation to alternate locations might not be appropriate. The degree to which extrapolation is useful will depend on ecological and/or sociological contexts. However, management of lekking grouse is, if anything, a complex problem, ${ }^{5}$ and as such, case studies of large-scale management efforts can provide lessons learned and salient hypotheses for future research. It is our hope that this article will promote a continued dialogue between managers, landuser groups, and researchers on the conservation of lekking grouse species.

\section{Greater Sage-Grouse}

Sage-Grouse Management on the Deseret Ranch, Utah Located in northeast Utah, Deseret Land and Livestock is a 200,000-acre working agronomic enterprise with a diversified base of operations that includes cattle ranching and commercial hunting for mule deer, elk, and pronghorn. Ranch biologist Rick Danvir emphasizes that Deseret is “ ... not a sage-grouse ranch" ... but is instead managed with multiple species and multiple uses in mind.

Much of Deseret's habitat consists of big sagebrush (Artemisia tridentata), in which historical disturbances such as fire influenced the condition of sage-grouse seasonal habitats. Desired habitat conditions for sage-grouse vary by life history stage, ranging from dense sagebrush cover for nesting and winter habitat to brood-rearing habitat that is characterized by a mix of sagebrush and more open patches that contain an abundance of forbs and insects (both of which are important for chick production). ${ }^{6}$ In this landscape, without periodic disturbance to reduce the sagebrush canopy, mountain big sagebrush can increase in abundance to levels that limit herbaceous plant diversity as well as the associated value of sage-grouse brood-rearing habitat. ${ }^{7}$

Management of the Deseret has focused on a balanced program to increase habitat diversity while maintaining profitability of their cattle enterprise. They are using a variety 


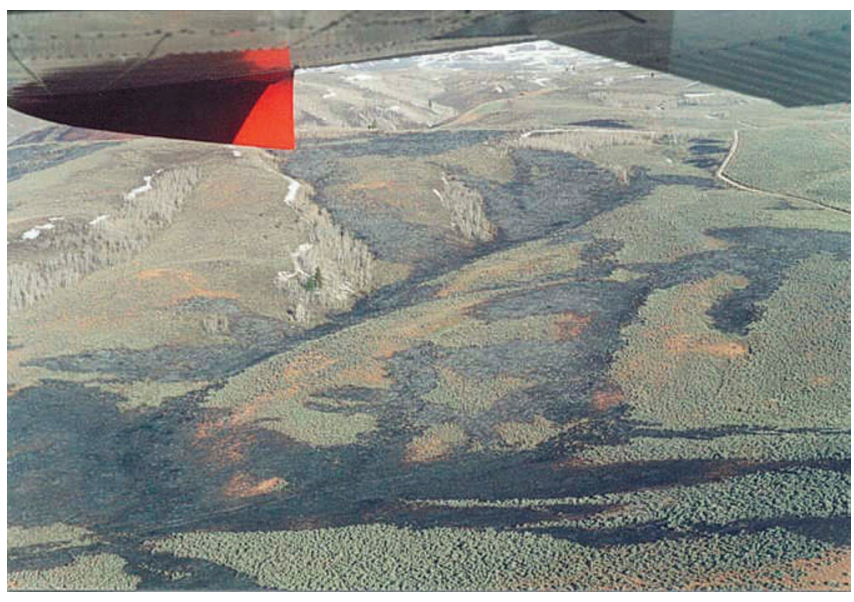

Figure 1. Aerial view of sagebrush mosaic resulting from spring burning. Research and management experience in Utah indicate that disturbed patches within mountain big sagebrush habitat provide important foraging habitat for sage-grouse. Image courtesy of Rick Danvir.

of tools to increase diversity in sagebrush habitat, including disking, seeding, soil aeration, prescribed fire (including spring burning), prescribed grazing, and sagebrush reduction with herbicide (Figs. 1 and 2). Grazing management focuses on keeping $90 \%$ of the cattle on $10 \%$ of the land area at any given time during the grazing season (1 April to 31 October) and resting $20-30 \%$ of the pastures annually. These processes result in structural openings within continuous sagebrush habitat that promote diversity of habitat conditions. Over the last 14 years, roughly 23,000 acres, or $20 \%$ of the sagebrush steppe habitat on the ranch, have been treated.

Experience with the process and an open-minded approach have allowed Deseret managers to tailor landscape habitat conditions to fit the needs of a variety of wildlife species. For sage-grouse, the results of this management program have been encouraging. Randy Larsen from Brigham Young University and Dave Dahlgren from Utah State University have worked with Deseret managers to complete a 20 -year retrospective analysis of sage-grouse populations on the ranch and at similar sites located within $50 \mathrm{~km}$ of the ranch under different management strategies. Results from their retrospective review show that most broods on the Deseret were found within $60 \mathrm{~m}$ of a habitat edge. Comparison with adjacent areas indicates that lek counts, lek persistence rates, and average brood sizes were higher on the Deseret than surrounding areas. Additionally, both grouse (estimated total number of grouse and average male lek attendance) and cattle numbers increased over the 20-year period associated with management actions at Deseret. Similar increases were not observed in the adjacent northern Utah or western Wyoming locations.

\section{Sage-Grouse Management in Montane Sites, Utah} David Dahlgren, Renee Chi, Michael Guttery, Eric Thacker, and Terry Messmer from Utah State University have been assessing the utility of Leopold's tools of habitat management
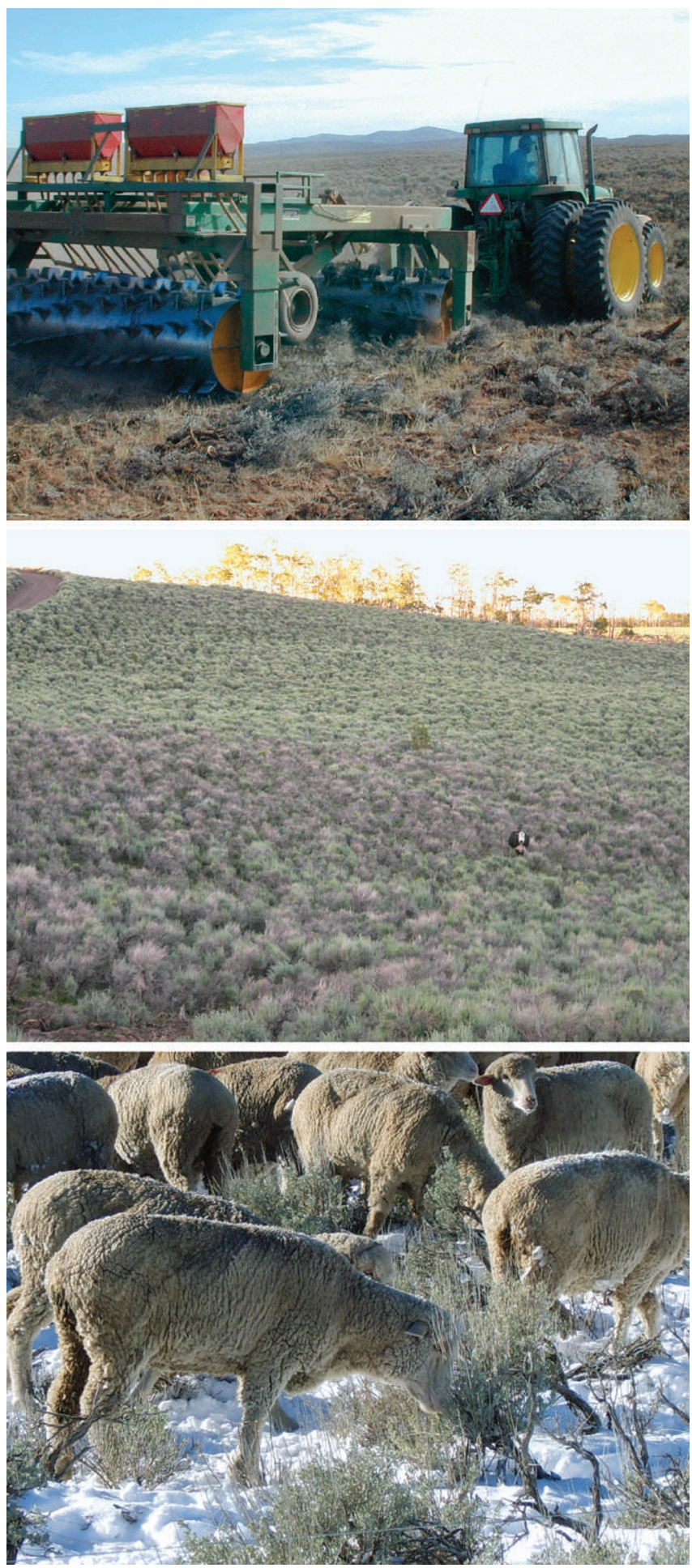

Figure 2. Small-scale reduction of shrubs using mechanical (top), partial-kill herbicide (middle), and grazing (bottom) treatments can be used to increase compositional and structural habitat diversity in high elevation sagebrush sites. These treatments have formed the basis of management plans that have produced notable increases in sage-grouse habitat quality at Deseret Land and Livestock and Parker Mountain in Utah. Treatments are applied mainly to breeding habitat at patch- to local-level scales. Large-scale shrub reduction is undesirable and negatively impacts both breeding and winter habitat. Sheep image courtesy of Michael Gutter; remaining images courtesy of Rick Danvir. 
(cow, plow, axe, and fire), for managing high-elevation (>7,500 feet) sage-grouse brooding habitat on Parker Mountain in south central Utah ${ }^{8,9}$ and Anthro Mountain in northeastern Utah. ${ }^{10}$ Early research indicated that low forb diversity in the brood-rearing habitat might be limiting sage-grouse production. They sought to evaluate management alternatives to increase the forb diversity in traditional brood-rearing areas. The specific habitat treatments they evaluated to open the sagebrush canopy included low-rate (matching soil type and depth) applications of herbicide $\left(\right.$ Spike $\left.^{\circledR}\right)$, mechanical manipulations (Lawson aerator, Dixie harrow), dormant-season (October-November) sheep grazing, and prescribed fire (fall) (Fig. 2). These treatments reduced the sagebrush canopy, as opposed to eliminating it (at least temporarily) from the plant community.

Traditionally, these manipulations have been used at large spatial scales, often to the detriment of sage-grouse when treatments result in elimination of or dramatic reductions in sagebrush. On Parker Mountain, Dahlgren and colleagues applied treatments in smaller blocks (e.g., mosaic designs treating 30 to $40 \%$ of 100 -acre mechanical and herbicide plots, eight acres for sheep grazing, and 20 to 225 acres for burns) within large blocks (many $\mathrm{km}^{2}$ ) of sagebrush. Broodrearing habitat conditions, based on changes in vegetation and observed sage-grouse habitat-use patterns, have improved: broods preferred locations within burned areas vs. unburned, pellet count density was higher in herbicide treated vs. control areas, and more grouse were located in fall sheep-grazed plots compared to ungrazed; disturbed areas generally had increased forb cover, which might explain this preference. Use patterns indicated that birds located in control and treatment plots were typically within $30 \mathrm{~m}$ of a habitat edge (e.g., dominant shrub type, road, treatment). This preference to remain near protective cover highlighted the importance of treating small areas over large block treatments when managing brood-rearing habitats.

Despite the positive response of grouse on Parker Mountain to increased habitat diversity in treated areas, Dahlgren stresses that the healthiest populations of sage-grouse are associated with large expanses of contiguous sagebrush cover. He emphasized that the role of the habitat manager is to create habitat resources through shrub reduction in small patches ("Think of the 'chips' in a chocolate chip cookie," says Dahlgren) to meet seasonal habitat requirements. The optimal proportion of the landscape occupied by those patches will vary, depending on seasonal habitat needs. For example, when managing for late brood-rearing habitat, up to $40 \%$ of the land base can be treated, but where late brood-rearing habitat overlaps with nesting/early brood rearing or wintering habitat, conservative sagebrush treatments (e.g., 20\% of land area) are more appropriate. Considering sagebrush type and ecological site are also important when determining best land management practices. For example, on Parker Mountain, mountain big sagebrush is typically not used in winter due to snowpack at higher elevations, but black

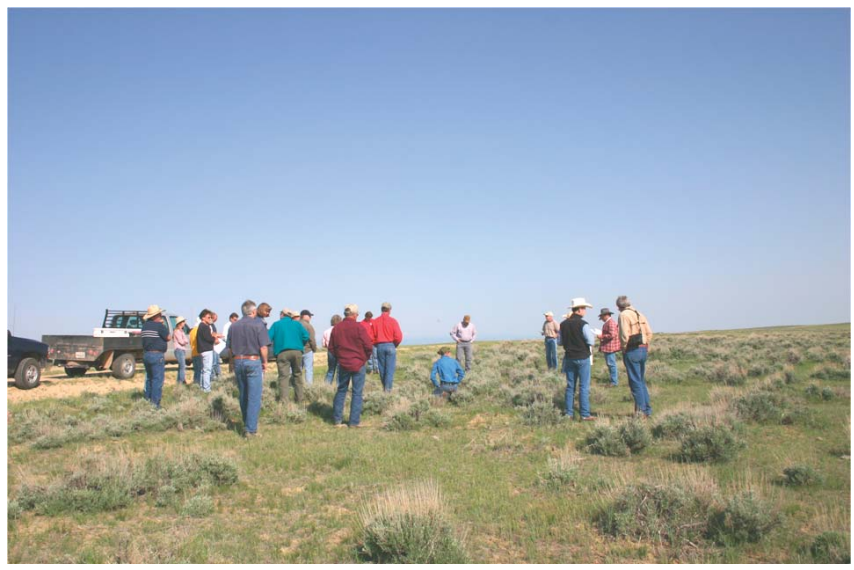

Figure 3. The Sagebrush/Grassland Restoration Project is bringing together ranchers and conservation groups in an effort to promote sagegrouse conservation at a landscape scale in Wyoming. At present, this project involves 24 ranchers who collectively control management on 340,000 acres. Biologists and Natural Resources Conservation Service (NRCS) Range Conservationists work with ranchers to conduct resource inventories, determine resource conditions and seasonal use patterns of sage-grouse, and create management plans that complement the habitat needs of sage-grouse and other wildlife species. Image courtesy of Nikki Lohse, Lake DeSmet Conservation District.

sagebrush (Artemisia nova) is critical during that time period. Additionally, lower elevation sagebrush types/ecological sites can respond differently to disturbance treatments, particularly in the presence of invasive annual grasses.

\section{Scaling-up for Regional Sage-Grouse Conservation}

Ultimately, issues with sage-grouse habitat management must be addressed on a regional scale, suggesting that effective management of the species and its habitat will require initiatives that draw together diverse interests into effective conservation efforts. One such program currently playing out in the Lake DeSmet Conservation District (LDCD) in central Wyoming is the LDCD Sagebrush/Grassland Restoration Project ${ }^{\mathrm{i}}$ (SGRP; Fig. 3).

Under the leadership of Natural Resources Conservation Service (NRCS) District Conservationist Phil Gonzales, the goal of this effort is to work with private landowners to replicate conservation practices of the Deseret Ranch and proactively increase sage-grouse populations, as well as other sagebrush-associated wildlife (e.g., mule deer and antelope), at the landscape scale. At present there are 24 private landowners and 340,000 acres enrolled in the program. Partner agencies and groups include the Wyoming Game and Fish Department (WG\&F), NRCS, the Wyoming Wildlife and Natural Resource Trust, the oil and gas industry, Bow Hunters of Wyoming, the Wyoming Governor's Big Game License Coalition, the Wyoming Governor's Sage-Grouse Fund, Pheasants Forever, the Wyoming Private

'Web site available at: http://www.ldcd.org/index_files/Page1290.htm. 
Grazing Lands Team, and Water for Wildlife, with the lead in partnership development coming from LDCD.

The heart of the SGRP is a grazing plan that focuses on key grazing strategies, including providing rest and recovery, variable season of use, allowing desirable plants to produce seed, leaving residual cover for wildlife, returning organic matter to the soil, and increasing management flexibility. Grazing plans are tailored to the needs and logistical capabilities of individual ranches and have been prepared for all landowners participating in the SGRP. Gonzales underscores the importance of understanding how sage-grouse use the landscape throughout the year and conveying that knowledge to producers so they can adapt management practices to complement objectives for sage-grouse habitat. To that end, LDCD and its partners have used global information systems (GIS) as a tool to map and analyze wildlife use and range condition, and both of these layers are being used to develop grazing plans that maintain economic viability of ranching operations while complementing the seasonal habitat use patterns of sage-grouse.

In addition to completing resource/wildlife inventories and grazing management plans for all enrolled landowners, the SGRP has applied habitat enhancement treatments on over 13,500 acres, purchased over 23,000 pounds of seed, installed 54 miles of fencing to implement grazing strategies, developed 74 watering facilities to provide water for wildlife and improve livestock distribution, installed 122 sage-grouse ramps in stock water tanks to provide escape routes for entrapped birds, developed about 18 miles of stock-water pipeline, and installed three wells and six solar systems to assist in implementing livestock grazing plans. Annual monitoring by the NRCS, WG\&F, landowners, and land managers provides feedback necessary to gauge the success of management efforts and iteratively improve best management practices.

Gonzales stressed that building trust with landowners is critical to the success of the SGRP. Repeated positive interactions with landowners helped lay the groundwork for developing the trust necessary for program acceptance, and producers now are seeing real benefits from their involvement in this process. These benefits come in part from knowing that they are not just reacting to issues driven by outside interest groups, but instead are taking proactive measures to improve management of sensitive species. Additionally, management practices resulting from SGRP grazing plans are helping to improve economic viability of some livestock operations. For example, producer Tom Lohse's plan focuses, in part, on increasing operational flexibility to better deal with livestock management during drought, which ultimately translates into more management options that offer increased benefits to sage-grouse. Lohse decreased livestock numbers and switched to a later calving date to avoid additional feed costs. Conception rates and calf weights have now increased, and Lohse sells the same number of pounds of beef while running fewer livestock. These practices have improved rangeland health and allow Lohse to leave cover and food for sage-grouse and other wildlife species.

\section{Prairie-Chickens in the Southern Plains \\ A Regional-Scale Perspective}

Researcher Sam Fuhlendorf has made important strides in understanding how habitat quality for prairie-chickens is impacted by a changing landscape in western Oklahoma, northern Texas, and southeastern Kansas. Lesser prairiechickens inhabit mixed grass prairie, often with strong components of shrubs, namely, shinnery oak (Quercus havardii) and/or sand sagebrush (Artemisia filifolia) and have experienced a decline in abundance dating to the 1930s. Fuhlendorf's work suggests that the amount of native prairie in the vicinity of declining and stable lesser prairie-chicken populations has not changed substantially, and that the single biggest factor associated with declining populations is the loss of shrubland habitat. ${ }^{11}$ Other authors have noted that survivorship of lesser prairie-chickens can vary inversely with shrub cover below a critical shrub threshold. ${ }^{12}$ This habitat loss is associated with conversion of shrub habitat to tree habitat due to encroaching conifers with declining fire frequency, and outright loss of shrub habitat due to cultivation. Fuhlendorf notes that tree-invaded habitat is 15 times greater on landscapes with declining populations as compared to landscapes with stable populations. The end result of this process is a dramatically fragmented landscape with isolated patches of suitable habitat.

Compared to lesser prairie-chickens, habitat for greater prairie-chickens is associated more with true prairie and less with mixed-shrub vegetation. In the Flint Hills of northeastern Oklahoma and eastern Kansas, Fuhlendorf has been disentangling associations between landscape patterns, management practices, and variable populations of greater prairie-chickens. One of the dominant land management practices in the Flint Hills is the use of annual spring burning to promote forage for cattle grazing (Fig. 4). Burning is typically followed by intensive early stocking of cattle. This is a tallgrass prairie ecosystem, and the effect of frequent spring fire combined with intensive grazing is to maintain a fairly homogenous cover and structure of tallgrass vegetation at large spatial scales. Under these management influences, the number of greater prairie-chickens within the Flint Hills region has been steadily declining, in contrast to more stable populations in South Dakota and Nebraska, where spring burning is infrequent. ${ }^{13}$ However, within the Flint Hills, at the Nature Conservancy's Tallgrass Prairie Preserve (TPP) greater prairie-chicken populations have been stable for the last two decades. In contrast to repeated annual burning at large spatial scales, management at the TPP focuses on burning at the patch scale to produce a mosaic of burned and unburned areas across the landscape in any given year. Cattle and bison within the TPP forage primarily on the young succulent growth within recent burns. Annual grazing can be intense within these patches, but because fire is relatively 


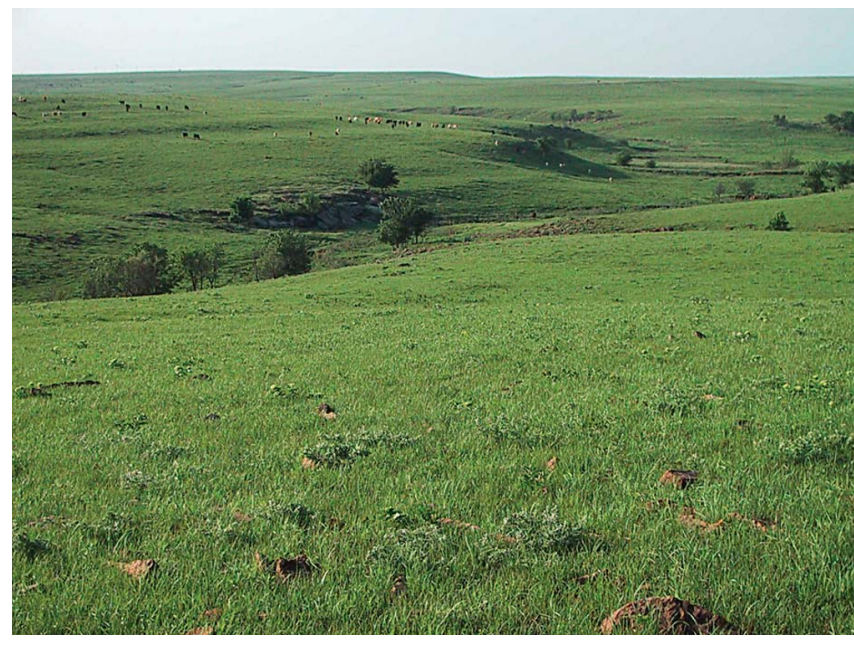

Figure 4. Annual spring burning, combined with intensive early livestock use, is associated with homogenization of large areas of tallgrass prairie in Oklahoma and Kansas, and also declines in populations of greater prairie-chickens. However, research in northeastern Oklahoma suggests that small-scale (i.e., patch) burning, combined with grazing, can create a shifting mosaic of successional stages that is associated with increasing greater prairie-chicken populations. Image courtesy of Sam Fuhlendorf.

infrequent at a given location, vegetation has adequate time for recovery. The net effect of this management process is to create a shifting mosaic of successional stages at the landscape scale that provides habitat conditions to fulfill the different life history requirements of greater prairie-chickens.

When viewed together, the problem sets facing lesser and greater prairie-chickens in the Southern Plains are in stark contrast. For example, lack of fire is allowing woody plant expansion in lesser prairie-chicken habitat, whereas too-frequent fire can negatively impact greater prairiechicken habitat; and lesser prairie-chickens populate a highly fragmented landscape (due to land conversion), but greater prairie-chickens are set within a comparatively homogenous area. In concept, however, the solution to these divergent issues remains largely the same, regardless of species; that solution is to promote a shifting mosaic of habitat composition and structure using grazing and periodic fire. Ultimately, local-scale management efforts could have more impact on greater prairie-chickens because they are set within a more intact landscape. Local efforts to improve habitat conditions for lesser prairie-chickens are likely to have less impact because their effectiveness is constrained by a highly modified landscape.

\section{Prairie-Chickens and the Conservation Reserve Program}

Much of the range of all the lekking grouse addressed in this article has been impacted by the Conservation Reserve Program (CRP), a federal program that promotes seeding of marginal croplands to permanent vegetation, usually grasses. Biologist Randy Rodgers with the Kansas Department of Wildlife and Parks has been part of an effort to document the effects of this program, particularly for lesser and greater

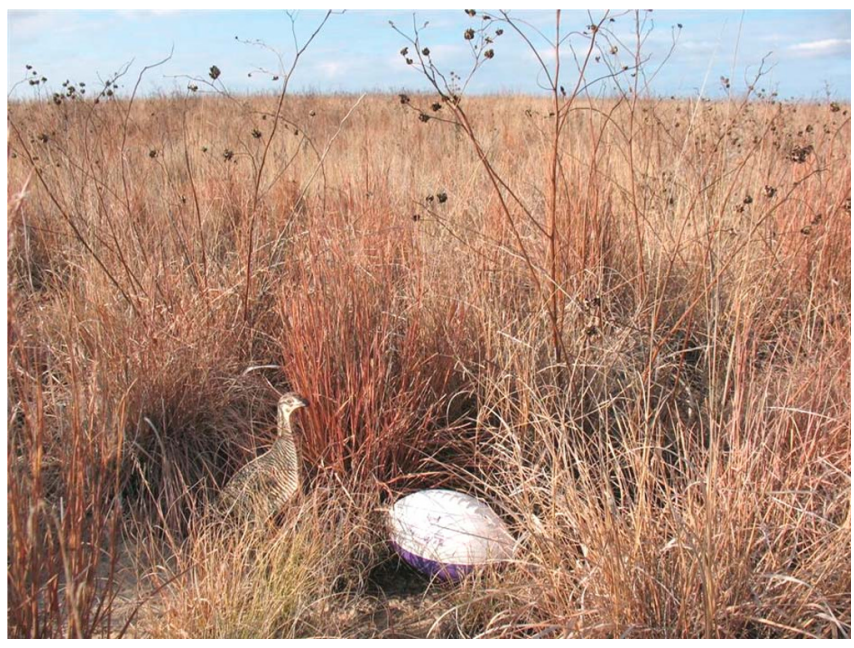

Figure 5. Prairie-chicken populations in western Kansas have benefitted from Conservation Reserve Program (CRP) stands that incorporated a diverse mix of native warm-season grasses and forbs, with vegetation ranging from mid-shin to mid-thigh height. Periodic disturbance is necessary to maintain forb abundance and an open habitat structure. Western wheatgrass and smooth brome have been invasive in many Conservation Reserve Program (CRP) stands, resulting in reduced structural and compositional diversity and diminished value for prairie-chickens. Interseeding of existing CRP with forbs such as alfalfa, provides structural heterogeneity and can increase invertebrate biomass (a high-protein food source) up to three-fold. Image courtesy of Randy Rodgers.

prairie-chickens ${ }^{14}$ and determine how the program might be altered to tailor specific practices to these species' needs.

Habitat structure and composition for prairie-chickens vary on a seasonal basis. Birds can use tall and mixed grass stands that provide good concealment for nesting habitat, but prefer less dense and more diverse communities for foraging and brood rearing. Ample insect availability in brood-rearing habitat provides a high-protein food source that is key to chick survival. Although CRP lands excel as nesting habitat and can be preferentially selected, quality nesting habitat alone cannot sustain prairie-chicken numbers over time. Brood-rearing and foraging habitat have suffered and continue to suffer as a result of CRP stands established as monoculture plantings, often with introduced species that minimize habitat diversity. Unfortunately, much of the acreage planted under the CRP falls into this category. One exception to that generalization is found in western Kansas.

When compared to many other regions, Rodgers found that CRP in western Kansas was associated with strong increases in both range expansion and populations of lesser and greater prairie-chickens. Increased performance in western Kansas might have resulted from CRP plantings that consisted predominately of a mix of native warm-season species dominated by little bluestem (Schizachyrium scoparium), sideoats grama (Bouteloua curtipendula) and switchgrass (Panicum virgatum) (Fig. 5). Additionally, a variety of habitat management practices have been applied to these CRP stands to create the structural and compositional heterogeneity 

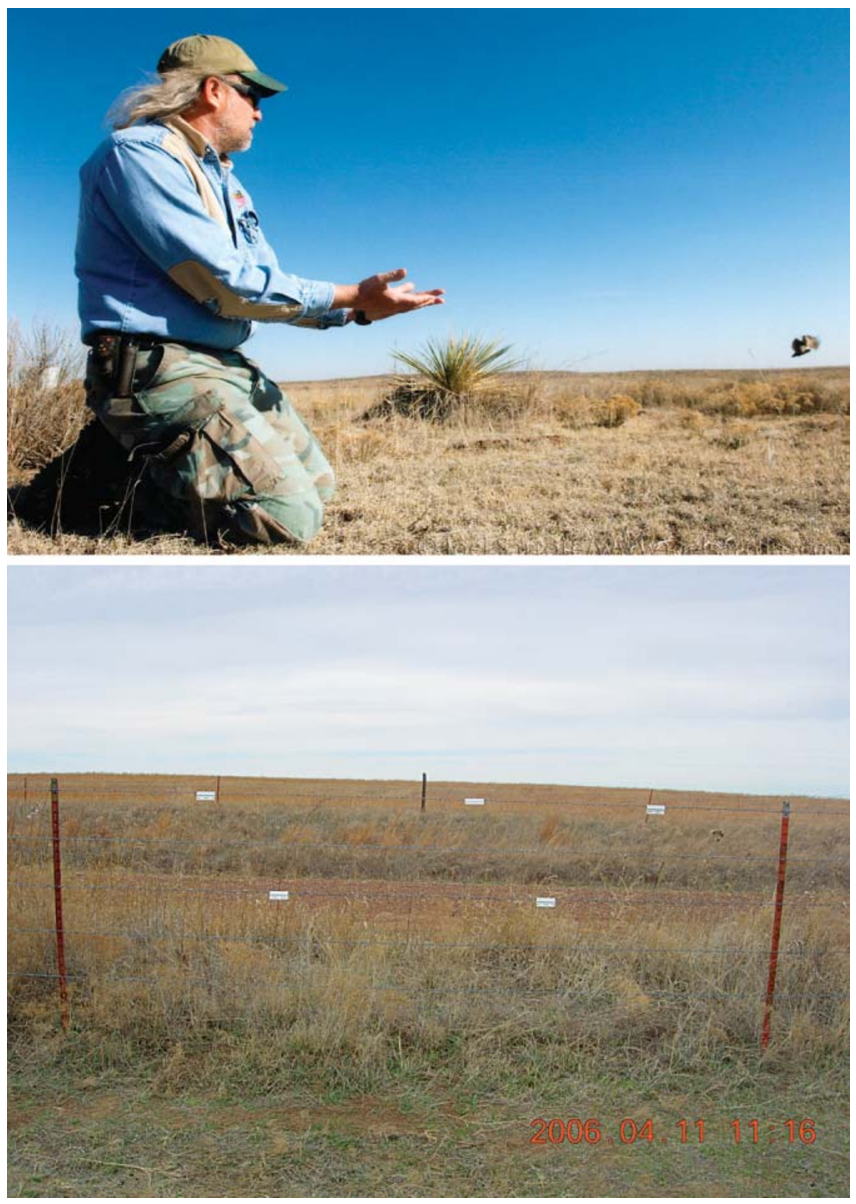

Figure 6. Lesser prairie-chickens fly fast and low to the ground, resulting in substantial mortality due to fence collisions. Here (top) biologist Don Wolfe releases a radio-marked lesser prairie-chicken. Ongoing research at the Sutton Avian Research Center in Oklahoma suggests that fence marking (bottom) with white plastic strips can dramatically reduce collision mortality. Top image courtesy of Joel Sartore/joelsartore.com; bottom image courtesy of Don Wolfe.

needed for year-round habitat. For example, interseeding of the CRP stands with forbs, such as alfalfa (Medicago sativa), has increased structural heterogeneity and has increased invertebrate biomass up to three-fold. Other practices used to create habitat diversity in CRP stands include livestock grazing, prescribed fire, and disking (often associated with fire-break installation) to promote forb abundance. Although nonaggressive introduced species such as alfalfa have been used in western Kansas CRP plantings, aggressive species such as smooth brome (Bromus inermis) and western wheatgrass (Pascopyrum smithii) have been strongly discouraged. The overall thrust of plantings here has emphasized compositionally (grasses, forbs, and shrubs where appropriate) and structurally diverse plant communities with stand heights from "shin to thigh high."

At larger scales, Rodgers found the greatest value of CRP to prairie-chickens was when it is planted adjacent to, or within two miles from an existing grassland habitat so that it created larger habitat blocks or increased the proportion of grassland in the landscape mosaic. Stands of CRP established adjacent to native range have been particularly valuable because the CRP provides good nesting habitat, and newly hatched broods can easily move into the native range, which provides better chick-foraging habitat. As mentioned earlier, lesser prairie-chickens in particular have suffered due to the expansion of trees into prairie ecosystems, and Rodgers strongly discourages planting trees or allowing the invasion of trees into CRP or native range.

\section{Don't Fence Me In}

Another issue for prairie-chickens in managed landscapes is the prevalence of livestock fencing. A fenced section of land contains four miles of fencing and that number goes up in proportion to the amount of cross-fencing. The abundance of fencing is particularly high in the Texas Panhandle ${ }^{15}$ and in Oklahoma where average parcel size is low (440 acres; D. Wolfe, personal communication, February 2010). Fences not only provide perch sites for raptors, but also cause direct mortality of birds through collisions, particularly for lowflying species such as lesser prairie-chickens that can hit speeds of 60-70 mph in flight (Fig. 6). Don Wolfe from the Sutton Avian Research Center in Oklahoma has been radio-marking lesser prairie-chickens in New Mexico and Oklahoma since the late 1990s and found that roughly 30\% of mortality of New Mexico birds and 50\% of mortality in Oklahoma was a result of fence collisions.

One obvious solution to this problem is to take out unnecessary fencing. However, fence removal is not feasible in many cases, so Wolfe and his colleagues have been searching for indirect methods to reduce fence collisions. Specifically, they have been evaluating a variety fence marking techniques that improve fence visibility. ${ }^{16}$ To date, they have gotten the best results using thin strips of vinyl siding fixed every $1-1.2 \mathrm{~m}$ to the top and third wires of a five-wire barbed-wire fence (Fig. 6). This type of marking is fairly economical (\$220/mile) and can be strategically located within the landscape around high-use areas such as active leks. Sutton Avian Research Center field crews have installed markers on over 156 miles of fences in Oklahoma, impacting an estimated 125,000 acres. They have monitored approximately 25 miles of fences for four years since marking, and over six years prior to marking. Annual mortality from fence collisions averaged 10 to 15 lesser prairiechickens for the test area prior to marking, but in the four years since marking, only one collision mortality has been documented.

\section{Greater Prairie-Chickens and Sharp-Tailed Grouse in the Central and Northern Plains A Tale of Two Grasslands}

Prairie grouse (i.e., greater prairie-chickens and sharp-tailed grouse) have undergone severe population declines and range contraction due to grassland conversion to cropland. 


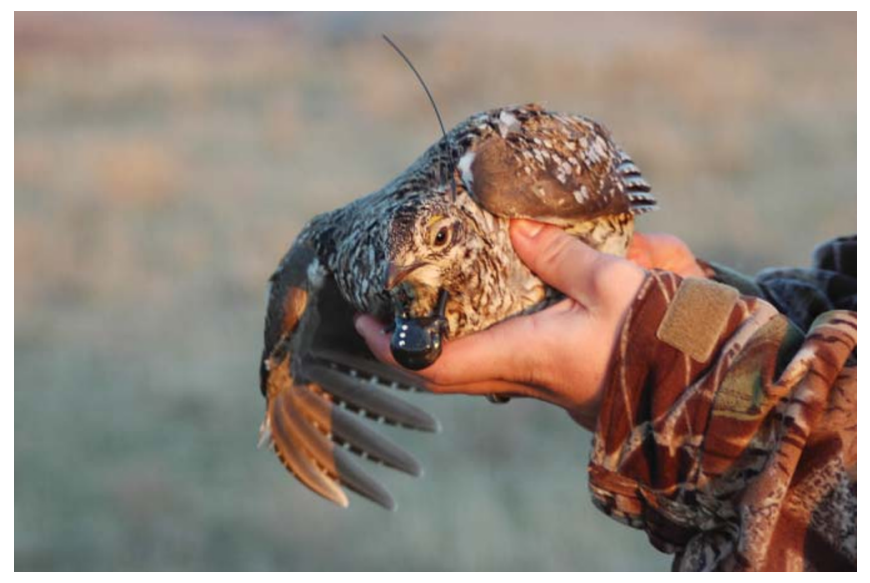

Figure 7. Radio-marked sharp-tailed grouse prior to release on Fort Pierre National Grassland in South Dakota. Researcher K.C. Jensen has found that grazing management practices can impact prairie grouse (sharp-tailed grouse and greater prairie-chickens) populations. In this study, hen survival, nesting success, and brood survival were higher in association with later turnout date (June vs. May), shorter grazing season ( 5 vs. 7 months), and an increased proportion of the landscape rested from grazing (18\% vs. 5\%). Image courtesy of K. C. Jensen.

This loss has accentuated the value of remaining habitats, most of which are grazed by livestock. Researcher K. C. Jensen and his graduate students have been studying the role of grazing in influencing prairie grouse habitat by comparing livestock grazing practices and prairie grouse habitat characteristics and population metrics on two divergently managed national grasslands (Fig. 7).

Located in central South Dakota, the Fort Pierre National Grassland (FPNG) is 40,000 acres of mixed grass prairie that is managed for multiple uses, including livestock and wildlife production, and outdoor recreation. Management of cattle grazing on the FPNG is focused on a rotational grazing regime with grazing from 1 June to 1 October. A minimum of $10 \%$ of the management area is rested annually, but actual use varies; for example, 20\%, 24\%, and 10\% of the management area was rested in 2003, 2004, and 2005, respectively. The Little Missouri National Grassland (LMNG) encompasses over 1 million acres of mixed grass prairie (with inclusions of shrub-steppe and woody draws) in western North Dakota and is managed for livestock forage production, recreation, oil and gas production, and conservation. Cattle grazing is allowed from 1 May to 1 December, and intensity of use varies by pasture. Management calls for 5\% of the grassland to be rested annually, but increased use is allowed during drought years.

From 2003 to 2007, Jensen and colleagues captured and attached transmitters to both greater prairie-chicken and sharp-tailed grouse on the FPNG, and sharp-tailed grouse on the LMNG. They tracked birds during the nesting and brood-rearing periods to determine areas of habitat use, nest success, and survival of hens and broods. They then compared habitat composition and structure between use and nonuse areas. Results from this study indicated that nest success and survival of hens and broods were higher on FPNG compared to LMNG (brood survival was nearly seven times higher). The FPNG had increased forb cover, which is critical for chick health, and the LMNG had only $25 \%$ to $30 \%$ of the available vegetative height structure (concealment cover) as compared to the FPNG.

Caution is certainly warranted when making direct comparisons of prairie grouse dynamics and management programs between these two grasslands. The studies were not conducted concurrently, and the grasslands are separated by nearly 300 miles. That said, the brood survival rates on FPNG are some of the highest ever recorded for prairie grouse. Jensen stresses that brood survival is key to sustaining prairie grouse populations and points to the high amount of cover as well as high forb availability as important habitat drivers influencing the success of prairie grouse at FPNG. Considering these habitat variables, the grazing strategy used at the FPNG promoted a diversity of vegetative structure and composition. This diversity can be associated with both within- and between-year components. For example, within year, a greater percentage of the landscape remains ungrazed at FPNG and, between years, concealment cover associated with residual vegetation is greater at FPNG because overall utilization is lower. These factors work to promote diversity at different time scales that ultimately can have a positive impact on reproductive success of prairie grouse and populations at FPNG.

\section{Management on the Valentine National Wildlife Refuge}

In the 1930s, 21 National Wildlife refuges (NWR) had populations of greater prairie-chickens. That number decreased over time, and by 1963, the Valentine NWR (VNWR) was the last NWR stronghold for greater prairie-chickens. Since that time, populations on the VNWR have markedly increased, and biologist Mel Nenneman has been piecing together the relationship between changes in management practices and the response of greater prairie-chicken populations (Fig. 8).

Established in 1935 and located in the Sandhills Region of northern Nebraska, the VNWR covers 71,772 acres of lakes, wetlands, and mixed grass prairie vegetation. Livestock grazing has been a traditional use of the VNWR area since European settlement. The extent of cattle grazing on the VNWR (61,680 acres of grassland) increased in the mid 1900s and peaked in the 1960s at levels approaching 40,000 animal unit months (AUMs). At peak usage, less than 10\% of the refuge was rested from grazing on an annual basis. Additionally, all of the productive subirrigated meadows on the refuge were hayed annually. Annual haying of meadows has now been largely eliminated, and reductions in AUMs were initiated in 1969. Grazing pressure has since declined linearly to the present-day level of about 5,000 AUMs. Current grazing strategies (since 1986) emphasize 


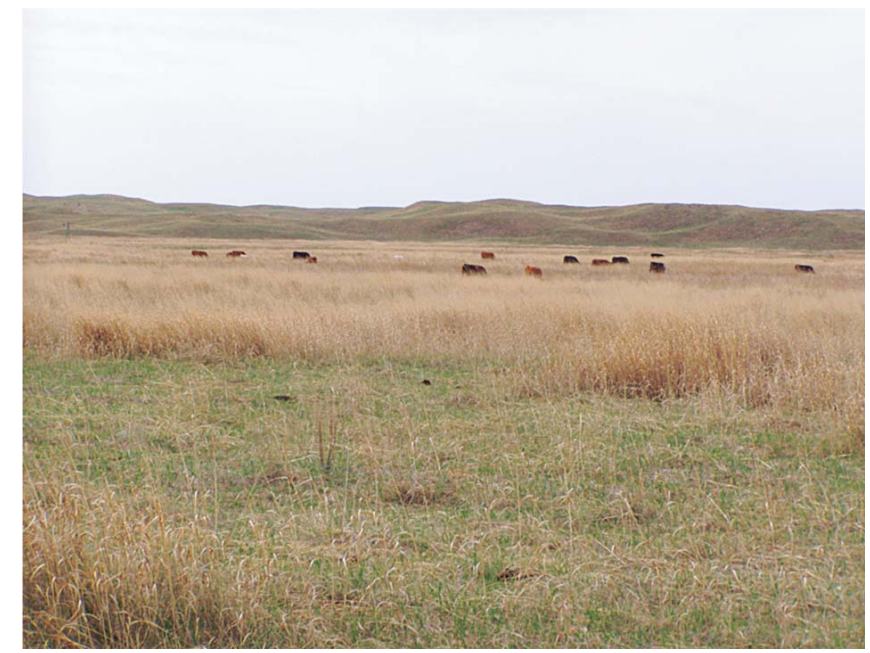

Figure 8. The Valentine National Wildlife Refuge in north-central Nebraska represents a true success story in greater prairie-chicken management. Historically, cattle grazed season-long across almost the entire refuge and all of the productive subirrigated meadows were hayed. During this time, greater prairie-chickens were present, but at dangerously low levels. Current management focuses on impacting (grazing and burning) approximately $40-45 \%$ of the refuge annually using short-duration summer grazing at dramatically reduced stocking rates. Additionally, annual haying of meadows has been almost entirely eliminated on the refuge. In response to these management changes, greater prairie-chicken populations have increased by an order of magnitude and have maintained this level for almost 20 years. Image courtesy of Wendy Austin/US Fish and Wildlife Service.

spring grazing treatments at about $0.55 \mathrm{AUM} /$ acre on approximately $40 \%$ of VNWRs subirrigated meadows, and short-duration summer grazing at about $0.2 \mathrm{AUM} /$ acre on approximately $45 \%$ of upland acres. This is in contrast to the season-long (summer, fall, or winter) grazing practices of years past. The VNWR has also initiated a spring burning program to reduce encroaching woody plant species, promote warm season grasses, and reduce invasion of Kentucky bluegrass (Poa pratensis). Between prescribed fire and grazing, about $30-40 \%$ of the refuge is currently disturbed on an annual basis, compared to a high of over 90\% in 1969.

Response of greater prairie-chickens to changes in refuge management has been dramatic. Monitoring efforts going back to the 1970s indicate that populations of greater prairie-chickens began to increase in the late 1970s and early 1980s, had doubled in numbers by the early 1990s, and have since fluctuated around that level. When the increasing population trend was compared with the percent of the refuge disturbed by grazing or fire, changes in percent disturbance explained nearly $70 \%$ of the fluctuation in greater prairie-chicken populations over time.

\section{Management Principles}

Group discussion at the symposium and the development of this article revealed commonalities in themes among presenters. One of the themes that came up repeatedly was the role of heterogeneity in influencing quality of lekking grouse habitat. In fact, this theme came up often enough that we began to wonder about the potential value of using the concept of heterogeneity as a principle to guide management efforts. ${ }^{17}$ To be useful as a management principle, heterogeneity as a concept must be explicitly defined. Heterogeneity is often thought of as the interspersion of different habitat types such as woodlands and grasslands. However, this definition has little use in prairie grouse or sage-grouse habitat where large expanses of one general habitat type are required. If we define heterogeneity as the interspersion of various successional stages (or states) of the same general habitat type (e.g., grassland or sagebrush steppe), then heterogeneity becomes a viable tool in managing seasonal habitats for both prairie grouse and sage-grouse.

Guidelines for habitat management of specific lekking species (e.g., work by Connelly and colleagues ${ }^{6}$ ) have traditionally served the dominant role in providing sideboards for management of habitat for various life history stages of avian species. However, application of guidelines is set within the context of environmental resources that vary both in space and time. Unfortunately, specific values for habitat parameters within guidelines are often misinterpreted as literal standards that should be applied across the range of a particular species, to the point where these values can substitute for local ecological knowledge of habitat resources and might be unattainable on some ecological sites. ${ }^{18}$

In theory, a management principle does not represent a specific end-point value, but rather encapsulates a concept that should have management utility over a wide range of habitats and years. For example, work on the Deseret Ranch and Parker Mountain in Utah suggests that heterogeneity of habitat structure and composition is important to managing for the suite of vegetation communities needed throughout the life history stages of sage-grouse. Or consider the positive response of lesser prairie-chickens to $\mathrm{CRP}$ stands that diversified the landscape mosaic and to management practices that increased heterogeneity within the CRP stands themselves. In Nebraska, greater prairie-chickens increased in response to changes in management that reduced homogeneity of disturbance across the landscape, and a similar association was noted for prairie grouse in the Northern Plains. These examples suggest that the principle of managing for heterogeneity could be key to providing quality habitat to a variety of lekking species.

Important to this discussion is the caveat that management for heterogeneity is bounded by the specific habitat needs of the lekking grouse species as modified by the current landscape condition. Too much heterogeneity, or heterogeneity made up of undesirable seral stages, can lead to fragmentation of useable habitat and have a negative 
effect on grouse species. For example, consider the fragmentation of lesser prairie-chicken habitat that is occurring as shrub communities are invaded by tree communities in the southern Plains. Or consider that high levels of heterogeneity can benefit late brood-rearing habitat for sage-grouse, but be negative for wintering and nesting habitat. Similarly, the spatial scale at which heterogeneity is gauged can affect our interpretation of its consequences to lekking grouse. For example, positive values associated with heterogeneity within a specific seasonal habitat can have negative consequences at the scale of a population's home range, if such heterogeneity precludes availability of other seasonal habitat types.

Ultimately, the best arrangement and spatial extent of heterogeneity will only be realized through the use of adaptive management to relate management manipulations to changes in avian populations. Modifying habitat heterogeneity can involve a variety of tools (e.g., burning, herbicides, mechanical treatments, alterations in grazing practices, new plantings). However, it is important for managers to maintain objectives that focus on biological metrics and the principle of developing heterogeneity, as opposed to the tools used to create those conditions. ${ }^{5}$ Tools and tactics will vary over space and time, but principles should not.

\section{Acknowledgments}

Melvin Nenneman thanks Len McDaniel for his thoughts on prairie grouse management at Valentine VNWR, and for sharing his knowledge of refuge management history. Chad Boyd wishes to thank Kirk Davies for his thoughtful review of the manuscript and helpful comments.

\section{References}

1. Schroeder, M. A., and L. A. Roвb. 1993. Greater prairiechicken (Tympanuchus cupido). In: A. Poole [ED.]. The birds of North America Online. Ithaca, NY, USA: Cornell Lab of Ornithology. Available at: http://bna.birds.cornell.edu.proxy. library.oregonstate.edu/bna/species/036. Accessed 8 July 2010.

2. Connelly, J. W., M. W. Gratson, and K. P. Reese. 1998. Sharp-tailed grouse (Tympanuchus phasianellus). In: A. Poole [ED.]. The birds of North America Online. Ithaca, NY, USA: Cornell Lab of Ornithology. Available at: http://bna.birds. cornell.edu.proxy.library.oregonstate.edu/bna/species/354. Accessed 8 July 2010.

3. Schroeder, M. A., J. R. Young, and C. E. Braun. 1999. Greater sage-grouse (Centrocercus urophasianus). In: A. Poole [ED.]. The birds of North America Online. Ithaca, NY, USA: Cornell Lab of Ornithology. Available at: http://bna.birds. cornell.edu.proxy.library.oregonstate.edu/bna/species/425. Accessed 8 July 2010.

4. Hagen, C. A., And K. M. Giesen. 2005. Lesser prairie-chicken (Tympanuchus pallidicinctus). In: A. Poole [ED.]. The birds of North America Online. Ithaca, NY, USA: Cornell Lab of Ornithology. Available at: http://bna.birds.cornell.edu.proxy. library.oregonstate.edu/bna/species/364. Accessed 8 July 2010.
5. Boyd, C. S., and T. J. Svejcar. 2009. Managing complex problems in rangeland ecosystems. Rangeland Ecology $\sigma^{\circ}$ Management 62:491-499.

6. Connelly, J. W., M. A. Schroeder, A. R. Sands, and C. E. Braun. 2000. Guidelines to manage sage grouse populations and their habitats. Wildife Society Bulletin 28:967-985.

7. West, N. E. 1983. Western Intermountain sagebrush steppe. In: N. E. West [ED.]. Ecosystems of the world. Volume 5: Temperate deserts and semi-deserts. Amsterdam, The Netherlands: Elsevier Science. p. 351-374

8. Dahlgren, D. K., R. Chi, and T. A. Messmer. 2006. Greater sage-grouse response to sagebrush management in Utah. Wildlife Society Bulletin 34:975-985.

9. Guttery, M. R. 2011. Ecology and management of a high elevation southern range greater sage-grouse population: vegetation manipulation, early chick survival, and hunter motiviation [dissertation]. Logan, UT, USA: Utah State University. 130 p.

10. Thacker, E. T. 2010. Greater sage-grouse seasonal ecology and response to habitat manipulations in northern Utah [dissertation]. Logan, UT, USA: Utah State University. 118 p.

11. Woodward, A. J., S. D. Fuhlendorf, D. M. Leslie, Jr., AND J. ShackFord. 2001. Influence of landscape composition and change on lesser prairie-chicken (Tympanuchus pallidicinctus) populations. American Midland Naturalist 145:261-274.

12. Patten, M. A., D. H. Wolfe, E. Shochat, and S. K. Sherrod. 2005. Effects of microhabitat and microclimate selection on adult survivorship of the lesser prairie-chicken. Journal of Wildlife Management 69:1270-1278.

13. Robbins, M. B., A. T. Peterson, and M. A. Ortega-Huerta. 2002. Major negative impacts of early intensive cattle stocking on tallgrass prairies: the case of the greater prairie-chicken (Tympanuchus cupido). North American Birds 53:239-244.

14. Rodgers, R. D., and R. W. Hoffman. 2005. Prairie grouse population response to conservation reserve grasslands: an overview. In: A. W. Allen and M. W. Vandever [eds.]. The Conservation Reserve-planting for the future. Proceedings of a National Conference, Fort Collins, CO, 6-9 June 2004. US Geological Survey, Biological Resources Division, Scientific Investigation Report 2005-5145. p. 120-128.

15. Patten, M. A., D. H. Wolfe, E. Shochat, and S. K. Sherrod. 2005b. Habitat fragmentation, rapid evolution and population persistence. Evolutionary Ecology Research 7:235-249.

16. Wolfe, D. H., M. A. Patten, and S. K. Sherrod. 2009. Reducing grouse collision mortality by marking fences (Oklahoma). Ecological Restoration 27:141-143.

17. Fuhlendorf, S. D., W. C. Harrell, D. M. Engle, R. G. Hamilton, C. A. Davis, and D. M. Leslie, JR. 2006. Should heterogeneity be the basis for conservation? Grassland bird response to fire and grazing. Ecological Applications 16:17061716.

18. Davies, K. W., J. D. Bates, And R. F. Miller. 2006. Vegetation characteristics across part of the Wyoming big sagebrush alliance. Rangeland Ecology \& Management 59:567-575.

Authors are Rangeland Scientist, USDA-Agricultural Research Service, Eastern Oregon Agricultural Research Center, Burns, OR 97720, USA, chad.boyd@oregonstate.edu (Boyd); Assistant Professor, Brigham Young University, Plant and Wildlife 
Sciences Department, Provo, UT 84602, USA (Petersen); Western Region Wildife Biologist, USDA-Natural Resources Conservation Service, West National Technical Support Center, Portland, OR 97232, USA, chad.boyd@oregonstate.edu (Gilgert); Wildlife Biologist, Kansas Department of Wildlife and Parks, Hays, KS 67601, USA (Rodgers); Sarkey's Distinguished Professor, Oklahoma State University, Natural Resource Ecology and Management Department, Stillwater, OK 74078, USA (Fublendorf); Assistant Professor, Brigham Young University, Plant and Wildlife Sciences Department, and the M. L. Bean Life Sciences Museum, Provo, UT 84602, USA (Larsen); Senior Biologist, G. M. Sutton Avian Research Center,
Bartlesville, OK 74005, USA (Wolfe); Associate Professor, South Dakota State University, Wildlife and Fisheries Sciences Department, Brookings, SD 57007, USA (Jensen); District Conservationist, USDA-Natural Resources Conservation Service, Buffalo, WY 82834, USA (Gonzales); Biologist, US Fish and Wildlife Service, Valentine National Wildlife Refuge, Valentine, NE 69201, USA (Nenneman); Wildlife Biologist, Deseret Land and Livestock, Woodruff, UT 84086, USA (Danvir); Postdoctoral Fellow, Utah State University, Wildland Resources Department, Logan, UT 84322, USA (Dablgren); Professor, Utah State University, Wildland Resources Department, Logan, UT 87322, USA (Messmer). 